 \\ International Journal of Social Sciences and Management
}

\section{A Rapid Publishing Journal}

ISSN 2091-2986

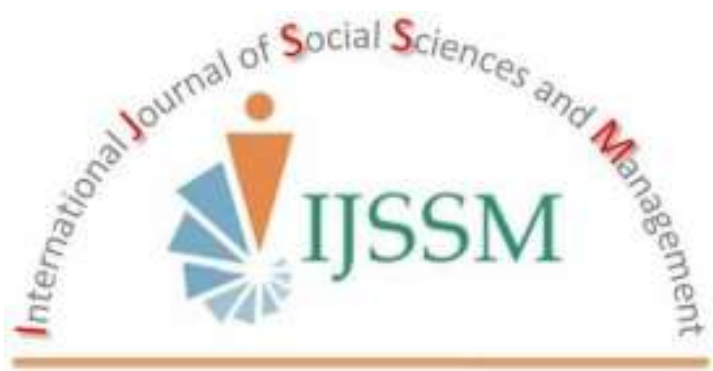

\section{Indexing and Abstracting}

CrossRef, Google Scholar, International Society of Universal Research in Sciences (EyeSource), Journal TOCs, New Jour, Scientific Indexing Services, InfoBase Index, Open Academic Journals Index (OAJI), Scholarsteer, Jour Informatics, Directory of Research Journals Indexing (DRJI), International Society for Research Activity (ISRA): Journal Impact Factor (JIF), Simon Fraser University Library, etc.

Vol- 2(4), October 2015 


\title{
EXPERIENCES IN HIGHER EDUCATION REFORM FOR SCIENCE, TECHNOLOGY \& ECONOMY DEVELOPMENT IN KOREA AND APPLICATION IN VIETNAM
}

\author{
Thi Ngoc Trang Bach ${ }^{1}$ and Hai Linh Tran ${ }^{2,3 *}$ \\ ${ }^{1}$ Department of Culture Management, Inha University, Incheon 402-751, South Korea \\ ${ }^{2}$ Association of Vietnamese Communities in Korea \\ ${ }^{3}$ Liaison Committee of Vietnamese experts in Korea \\ Corresponding author's email: hailinhtran@gmail.com
}

\begin{abstract}
The main purpose of this paper is to introduce Korea's process of education reform and achievements at university level, human resource training for the development of science, technology and economics and lessons that can be applied to Vietnam's education. Firstly, the paper would like to generally assess periods of education at university level, in which some matters related to education reform. Secondly, the paper values achievements in Korea's higher education linking to the development of science, technology and economic growth. Thirdly, the paper refers to Korean national policies and programs for higher education to reveal how they effectively affect to the development of university level education, science and technology. Finally, the authors give the opinions on the possibility of applying some experiences from Korea to Vietnam.

Keywords: Education reform; Universalization; Human resource training

\section{Overview}

For a half of century, Korea has started the process of universalization in higher education. In addition to this process and the development of national economics, Korea achieved surprisingly economic growth from the mid-1960s to the mid-1990s. Within 3 decades, Korea's annual average growth rate reached $8.4 \%$. In 1996, Korea became a member of the Organization for Economic Co-operation and Development (OECD, 2000). How could Korea obtain such impressive achievement? This question raises concerns for the developed and developing countries in over the world. Therefore, understanding Korea's experience

and achievements in university education is very important and this will provide international policy makers valuable ideas.

Since the end of $19^{\text {th }}$ century, the development of higher education in Korea has affected by the spiritual and realistic factors, such as activities by Christian missionaries throughout the period of Japanese and Americans colonial control, traditional religious philosophy and ideology, domestic and international socio-political factors, government policies on national economics and industry and the demand of high skilled human resource based on the solid background of knowledge (Lee, 2000b).
\end{abstract}

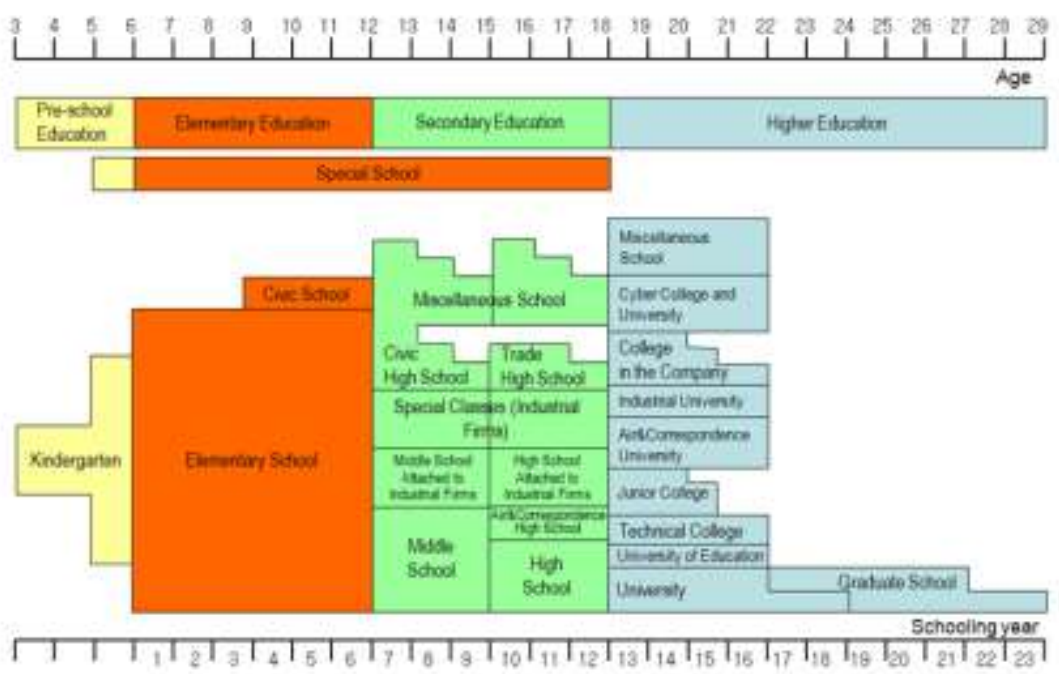

Fig. 1: Education system in the Republic of Korea (source from Lee, 2009) 
During the development of Korean higher education, the relationship between government and the higher education is very close. The government issued the reasonable policies to reform the higher education to produce high skilled human resources, developed the science and technology, and linked to the industry's development. And these have made the development of the national economy. Korea and Vietnam has many similarities in culture and history, the achievements obtained by Korea therefore could be applied to some fields in Vietnam. Accordingly, the purpose of this paper is to analyze main factors of achievements in higher education reform by Korea; policies and programs that considerably affect to high skilled human resource training and significantly contribute to the development of science and technology, applied the achievements of science and technology in industries and create "jostle" for the strong development of Korean economics. Consequently the paper would like to make recommendations for the applications to Vietnam.

\section{Experiences in Education Reform in Korea}

Korean liberation from 35-year Japanese occupation (19101945 ) on August $15^{\text {th }} 1945$ was a turning-point in its history of education. Under support of US (1945-1948), Korean government made an absolute reform of democratic university education and wiped out the remains of Japanese education. This was made by an introduction of American education; university education was reorganized and become more democratic and widely opened to all Korean. After foundation of the Republic of Korean in 1948, the newborn Korean government issued the Law of Education on December 31, 1949 to set up a new education system (Table 1).

Table 1: Education reform progress in the Republic of Korea

\begin{tabular}{|c|c|c|c|}
\hline $\begin{array}{c}1^{\text {st }} \text { Phase } \\
(1945-1960)\end{array}$ & $\begin{array}{c}2^{\text {sd }} \text { Phase } \\
\text { (1961-1979) }\end{array}$ & $\begin{array}{c}3^{\text {st }} \text { Phase } \\
\text { [1980-1997] }\end{array}$ & $\begin{array}{c}4^{\text {st }} \text { Phase } \\
\text { (1998-Present) }\end{array}$ \\
\hline $\begin{array}{l}\text { - Independence } \\
\text {-Korean War } \\
\text {-Reconstruction }\end{array}$ & $\begin{array}{l}\text {-Industrialization } \\
\text {-Urbanization }\end{array}$ & $\begin{array}{l}\text { Democratization } \\
\text {-Stabilized Economic } \\
\text { Growth }\end{array}$ & $\begin{array}{l}\text {-Globalization } \\
\text {-Knowledge-Based } \\
\text { Society } \\
\text { •ICT Society }\end{array}$ \\
\hline
\end{tabular}

Source: (Baek, 2013)

Table 2 shows that from 1945 to 1960 , major policies on higher education are to widen democratic education. In this period, Korean university education strongly developed from 19 universities and 7819 students to 85 universities and 101,041 students (Ministry of Education, 1976). After a coup d'état in 1961, the Korean military government recognized necessity of education reform to industrialize the country as well as to develop its national character. To meet the demand of education reform, the government reformed laws and administrative system of university education. On the other hand, in 1962, the government upgraded training lecturers from high school to college's level and institutes for training teachers of secondary school level were abrogated (Ministry of Education, 1998a). On December $5^{\text {th }} 1968$, Charter of National education was issued to recover national spirit and education reform (Ministry of Education, 1998). In the 1970s, the national policies on education were diversified to meet the demand of fast change of socio-economy.

Table 2: Some important step in education reform of the Republic of Korea

\begin{tabular}{|c|c|c|c|c|}
\hline $\begin{array}{l}\text { Development } \\
\text { phase (Period) }\end{array}$ & $\begin{array}{l}1^{\text {st }} \text { phase } \\
(1945-1960)\end{array}$ & $\begin{array}{l}2^{\text {nd }} \text { phase } \\
(1961-1979)\end{array}$ & $\begin{array}{l}3^{\text {rd }} \text { phase } \\
(1980-1997)\end{array}$ & $4^{\text {th }}$ phase (1998-present) \\
\hline $\begin{array}{l}\text { Phase of } \\
\text { Manpower Supply }\end{array}$ & $\begin{array}{l}\text { - Literate and } \\
\text { manually skilled } \\
\text { workforce } \\
\end{array}$ & $\begin{array}{l}\text { - Semi skilled and } \\
\text { skilled workforce }\end{array}$ & $\begin{array}{l}\text { - Highly skilled and } \\
\text { educated workforce }\end{array}$ & $\begin{array}{l}\text { - Knowledge /ICT } \\
\text { workforce }\end{array}$ \\
\hline $\begin{array}{l}\text { Important Social } \\
\text { Movement }\end{array}$ & $\begin{array}{l}\text { - Adult Literacy } \\
\text { Campaign } \\
\text { - Establishment of } \\
\text { Schools } \\
\text { - Universities by } \\
\text { private donors } \\
\end{array}$ & $\begin{array}{l}\text { - Saemaul Undong } \\
\text { (New Community } \\
\text { Development } \\
\text { Movement) }\end{array}$ & $\begin{array}{l}\text { - Mass Higher } \\
\text { Education } \\
\text { - Pursuit of Education } \\
\text { Substantiality }\end{array}$ & $\begin{array}{l}\text { - Globalization } \\
\text { - Enforcement of } \\
\text { Educational Reformation } \\
\text { and Competitive Power }\end{array}$ \\
\hline $\begin{array}{l}\text { Phase of } \\
\text { Education } \\
\text { Development }\end{array}$ & $\begin{array}{l}\text { - Setting basic } \\
\text { educational system } \\
\text { - Universal Primary } \\
\text { Education }\end{array}$ & $\begin{array}{l}\text { - Universal } \\
\text { Secondary } \\
\text { Education } \\
\text { - Implications of } \\
\text { Vocational } \\
\text { Education Training } \\
\end{array}$ & & \\
\hline Policy Choices & $\begin{array}{l}\text { - Compulsory } \\
\text { Education } \\
\text { - Reconstructing } \\
\text { educational facilities }\end{array}$ & $\begin{array}{l}\text { - Abolishment of } \\
\text { Middle School } \\
\text { Entrance Exam } \\
\text { - High School } \\
\text { Equalization Policy }\end{array}$ & $\begin{array}{l}\text { - Reform in July 30, } \\
1980 \\
\text { - Decentralized local } \\
\text { autonomy of } \\
\text { education }\end{array}$ & $\begin{array}{l}\text { - National HRD Policy } \\
\text { - Reconstructing Higher } \\
\text { Education (BK21) } \\
\text { - Lifelong Education } \\
\text { - ICT }\end{array}$ \\
\hline
\end{tabular}

Summarized from (Baek, 2013) 
In March 1985, an event that raised concerns was the establishment of advice committees of education reform, which were directly under president's supervision. The committees recommended president to reconsider education competitiveness. To maintain competitive advantage, education reform was unavoidable. In 1994, president's committees of education reform (PCER) were set up with the aim to create "a new Korea". A report by PCER was submitted to president, in which 2 significant tasks were focused: one was to enhance global competitiveness; the second was to improve entrance exam system. On May $31^{\text {st }}$ 1995, the first plan for education reform with 9 core tasks was issued to make a new frame for open education (Lee, 2000b).

The 9 core tasks were: setting up an opening education system, diversification and professionalization of university, creating a school society with democracy and self-control, focus on creativeness of teaching program, renewing entrance exam, developing a diversified education program, setting up a new assessment system, adjusting teacher training program, increasing budget for education to $5 \%$ GNP. The first two tasks implemented were diversification and professionalization of university to improve education quality (Ministry of Education, 1998b). In February and August 1996, the second and the third plan was respectively carried out, and the forth one was implemented in 1997. Despite of experiencing "global economic crisis", the Korean government continued the plans of reform made by the former governments. To put reform tasks into effect, advice committee of education was established in July 1998 and the Mistry of Education issued a full plan of "The five year education development" in 1999 (Ministry of Education, 1999). In conclusion, the majors of Korean education today are implemented in the direction of high quality, diversification, self-control and globally high competitiveness.

\section{Widening Education and Economic Growth}

After the Korean War, the development of post-graduate education in foreign countries and Korea are urgently needed. The first step is choosing brilliant persons from the universities, institutes and schools, and then providing training courses in the US. The Minnesota Project is done to train professors of Seoul National University, and set the "standard rule for all universities, graduate schools" in 1952. In that effort, the Higher Education workforce has improved significantly with 1,115 professors were trained abroad from 1953 to 1957 as a resource for the development of higher education in South Korea. And the following years, Korea continues to make the national policy to invite oversea Korean professors and doctors returning to Korea to work, teach and research.

In 1962, the Korean military government started the first five-year plan for economic development to enhance its national work of industrialization. In the mid-1960s and early 1980s, the government issued 4 plans for economic development and each plan lasted for 5 years and national policies were applied to speed up industry and export. The government issued policies to stimulate widening of university education and considered it as the nucleus means to train human resource, in terms of quality.

The attainment of the universalization in higher education, the qualitative improvement in higher education has become a principal goal of national policy since 1990s. The present Korean government recognizes that "the changes in the marketplace engendered by technological advance and globalization have rendered labor-intensive manufacturing obsolete and no longer dependable as an initiative factor in economic growth" (Ministry of Education, 1998). The government regards higher education as a prime motivator for the establishment of a high-quality manpower system as well as for the extension of national power. As an emphasis is placed on occupying a competitive edge in the international marketplace, the quality improvement of higher education is now considered as a viable option for the 21 st century. The Korean government has executed several national policies and tasks of higher education. The four major strategies are: innovated the college/university admissions policy, promoting research universities and strengthening of regional universities, re-engineering the overall college/university education system, and constructing a sound vocational and technical education.

In the late 1990s, the Ministry of Education and Human Resource Development started to carry out Brain Korea 21 program (BK21). The mission of BK21 is to develop research universities compete globally, offer post-graduate programs and provide high-quality human resources in Korea. The program aims to provide scholarships for graduate students, postdoctoral fellows in research groups at leading universities. Those are selected based on the scientific achievements. BK21 program does not support labor costs for faculty participation in study group, it only grants research fund to recruit and maintain teams of post graduate students and young researchers to perform research.

BK21 program divided into two phases. In the first phase, from 1999-2005, BK21 funded research groups, universities approximately 1.4 billion US dollars. In the second phase, started in 2006 and implemented by 2012, BK21 allocated 2.1 billion US dollars. BK21 has attracted a lot of attention because of its impressive outcome, demonstrated by the development of high skilled human resources, breakthrough advancements in science and technology, and their applications in industry and economy of South Korea. In the phase 1 only, the program trained 437,220 graduate and post-graduate students, and 431,824 SCI research papers were published (Soh, 2013). SCI paper publication's ranking in the world was improved from $18^{\text {th }}$ in 1998 to $12^{\text {th }}$ in 2007. Phase 2 of the BK21 program enhanced the quality of researches in Korea. The average number of publications in SCI journals per faculty member 
or researcher rose from 1.9 in 1999 to 2.43 in 2005 . Because of these positive outcomes, the Deutsche Bank Research Institute called BK21 "a true success story built upon highquality human resources, strong research infrastructure, and enhanced graduate school education" (Lee et al., 2012). And from 2013 to present, the program "BK21 Plus" has been continuing to promote scientific and technological researches.

Table 3: Numbers of students in Korean Universities in 2008, distributed to the fields of study

A. Colleges and Universities

\begin{tabular}{|c|c|c|c|c|c|c|c|c|}
\hline Glassification & & Humanities & $\begin{array}{l}\text { Social } \\
\text { Scioncess }\end{array}$ & Etucation & Enginteding & $\begin{array}{l}\text { Natural } \\
\text { Sciences }\end{array}$ & $\begin{array}{l}\text { Metical } \\
\text { Sciences \& } \\
\text { Pharmacy }\end{array}$ & $\begin{array}{l}\text { Arts } 2 \\
\text { Plysicsl } \\
\text { Edocation }\end{array}$ \\
\hline \multirow{4}{*}{ Grand Total } & Total & 393,262 & 938,797 & 195,243 & 854,333 & 333,054 & 180,934 & 365,809 \\
\hline & National & 121,682 & 165,550 & 100,793 & 204,710 & 120,752 & 23,959 & 33,595 \\
\hline & Public & 3,019 & 12,628 & 634 & 19,136 & 4.737 & 778 & 4,449 \\
\hline & Private & 268,561 & 760,619 & 93,816 & 630,487 & 207,565 & 156,197 & 327,765 \\
\hline
\end{tabular}

\section{B. Graduate Schools}

\begin{tabular}{|c|c|c|c|c|}
\hline \multicolumn{2}{|c|}{ Classification } & Total & Master's Degree & Doctor's Degree \\
\hline \multirow{4}{*}{ Grand Total } & Total & 301,412 & 252,010 & 49,402 \\
\hline & National & 85,306 & 70,417 & 14,889 \\
\hline & Public & 4,378 & 3,711 & 667 \\
\hline & Private & 211,728 & 177,882 & 33,846 \\
\hline
\end{tabular}

Source: (Lee, 2009.

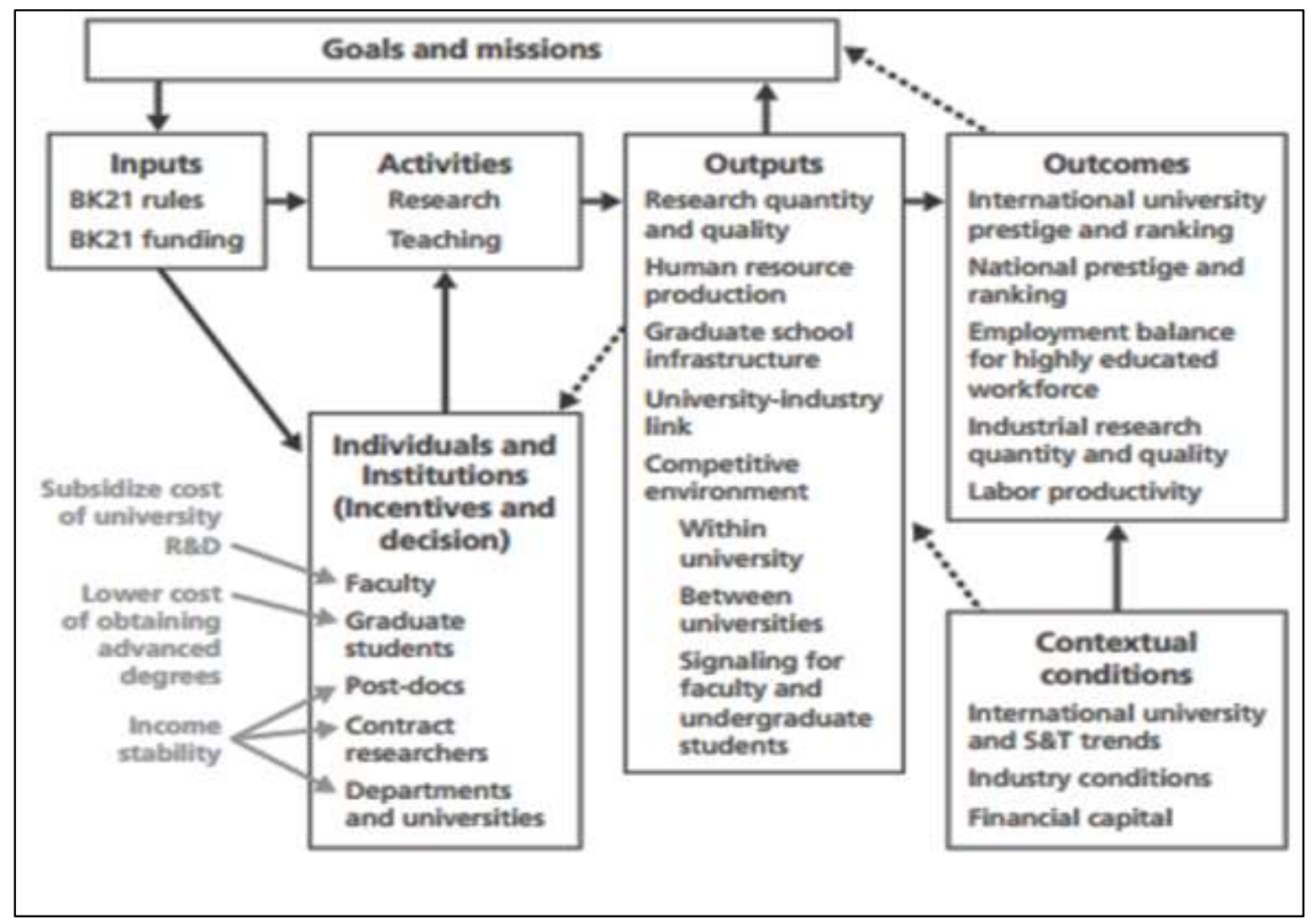

Fig. 2: Goals and missions of BK21 program. (Source: Seong, 2008) 
Table 4: Number and rank in the world of Patents and SCI papers from Korea (source: United States Patent and Trademark Office \& Korea Industrial Technology Association. Summarized from (Chung, 2010)

\begin{tabular}{|c|c|c|c|c|c|c|}
\hline Patent & 1985 & 1990 & 1995 & 2000 & 2005 & 2007 \\
\hline Number & 41 & 225 & 11,161 & 3,314 & 4,352 & 6,295 \\
\hline Rank in the world & - & 9 & - & - & 7 & 4 \\
\hline \multicolumn{7}{|l|}{ Source: USPTO } \\
\hline SCl paper & 1980 & 1985 & 1993 & 1997 & 2000 & 2007 \\
\hline Number & 171 & 1,227 & 2997 & 9,124 & 12,245 & 25,494 \\
\hline Rank in the world & - & 37 & 27 & 17 & 16 & 12 \\
\hline
\end{tabular}

- Source: ROITA

The WCU project, introduced in 2008, aims to recruit an international "star faculty" and thereby develop world-class academic departments and, eventually, world-class universities. WCU has three types of programmes. Some establish new academic departments or specialized majors in collaboration with full-time international scholars and the Korean faculty. Others employ full-time international scholars in existing academic programmes to teach and/or collaborate. And some invite world-renowned international scholars to teach and/or collaborate part time in existing academic programmes. To achieve these goals, the government planned to invest 825 million US dollars five years, started in 2008 (Lee et al., 2012).

Therefore, university education can be considered as a motive for Korea's economic growth, a means to raise individuals' economic position in society, which is built on the Confucian values (Lee, 2000a). Korean people has a long tradition with respect to study, which is derived from Confucianism, however, it is considered as a barrier for Korea to modernize industry and build up a modern system of education. Nonetheless, the respectful attitude to study is a positive value that contributes to Korea's university education and the development of science and technology as well as the economy. In short, Korean industries depended more on informal channels for technology acquisition than formal channels. As informal channels involve less market mediation and more active roles of technology recipients, they are less costly but require higher capability of technology recipients in not just identifying and selecting technologies but also absorbing, assimilating and improving upon the transferred technologies (Kim, 1997). This means that Korea has been able to succeed in acquiring technologies for industrialization largely owing to the rich pool of well-educated people who are determined to work for the betterment of their lives.
Korean industries have been able to increase $R \& D$ investments at such rapidity, thanks to the abundant pool of highly-educated manpower. R\&D investment has since undergone a quantum jump. Korea's R\&D investment, which stood at only 368.8 billion Won (526 million US dollars, $0.81 \%$ GDP) in 1981, rose to 10,878 billion Won (13.5 billion US dollars, $2.8 \%$ of GNP) in 1996, to 13,848 billion Won (12.2 billion US dollars, $2.7 \%$ of GDP) in 2000, to $31,301.4$ billion Won (33.7 billion US dollars, $3.47 \%$ of GDP) in 2007 (Chung, 2010), and to over 60 trillion won in 2013 (approximately $4.5 \%$ of GDP) (Fig. 3). Korea invests in R\&D a lot more of its income than others with the same or higher income. Korea now is the $6^{\text {th }}$ largest spender in R\&D among OECD countries. R\&D efforts have also contributed to the development of high-tech industries in Korea. Korea's technological competitiveness in semiconductors, displays, cellular phones, computers, telecommunication equipment and so on are partly the results of the government-industry collaborative R\&D. Considering the contribution of these technologies to the Korean exports and economic growth, we can get a rough idea on the relationship between R\&D and innovation and the socio-economic changes in Korea. (Chung, 2010).

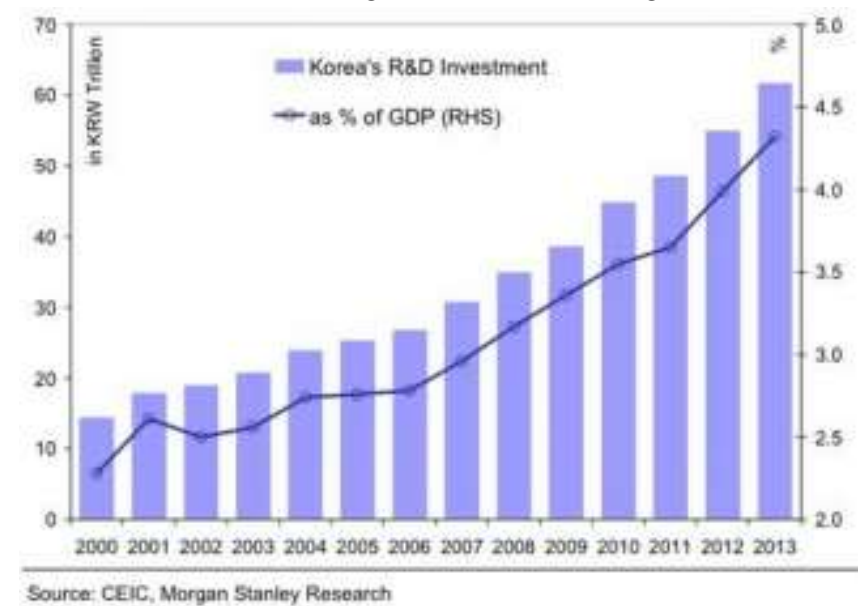

Fig. 3: Rising Investment from Korea's GDP (Source: Sam Ro, 2014)

Korea's exports are highly concentrated on high-tech products, such as semi-conductors, telecommunication equipment, displays, and so on. The share of high-tech and high-medium-tech products in Korea's exports increased from $13.45 \%$ in 1980 s to 43.2 in the 2000s. The drastic changes in the technological components of Korea's export products well explain the technological developments Korea has gone through over the past three decades or so (Chung, 2010).

R\&D stock's contribution to economic growth has been increasing along with economic development. From 1965 to 1985 , industrial field contributed to GNP from $20 \%$ to $30.5 \%$, meanwhile GNP in the agriculture decreased from $38 \%$ to $12.5 \%$. In 2013, GNP per capital in Korea reached 25,997 US dollars (Fig. 4). 
T.N.T. Bach and H.L. Tran (2015) Int. J. Soc. Sci. Manage. Vol-2, issue-4: 346-356

Table 5: The change of export share industries in the Republic of Korea (source from Chung, 2010)

\begin{tabular}{|c|c|c|c|}
\hline & Industries & $\begin{array}{l}\text { Export share } \\
\text { in } 1990(\%)\end{array}$ & $\begin{array}{l}\text { Export share } \\
\text { in } 2007\end{array}$ \\
\hline \multirow{4}{*}{$\begin{array}{l}\text { Declining share } \\
\text { in world trade }\end{array}$} & Primary industries & 4.9 & 1.5 \\
\hline & Textiles & 22.7 & 3.7 \\
\hline & Shoes & 6.6 & 0.1 \\
\hline & Home appliances & 11.3 & 3.7 \\
\hline \multirow{2}{*}{$\begin{array}{l}\text { Maintaining share } \\
\text { in world trade }\end{array}$} & Steel and iron & 6.7 & 6.2 \\
\hline & Computers & 3.9 & 3.7 \\
\hline \multirow{7}{*}{$\begin{array}{l}\text { Increasing share in } \\
\text { world trade }\end{array}$} & Petro-chemicals & 2.0 & 7.8 \\
\hline & Automobiles & 3.0 & 10.1 \\
\hline & Precision machineries & 2.8 & 6.9 \\
\hline & Telecomm equipment & 0.8 & 8.3 \\
\hline & Semi-conductor & 7.0 & 10.6 \\
\hline & Flat displays & 0.0 & 4.5 \\
\hline & Ships & 4.3 & 6.5 \\
\hline
\end{tabular}

Source: Rearranged from KITA

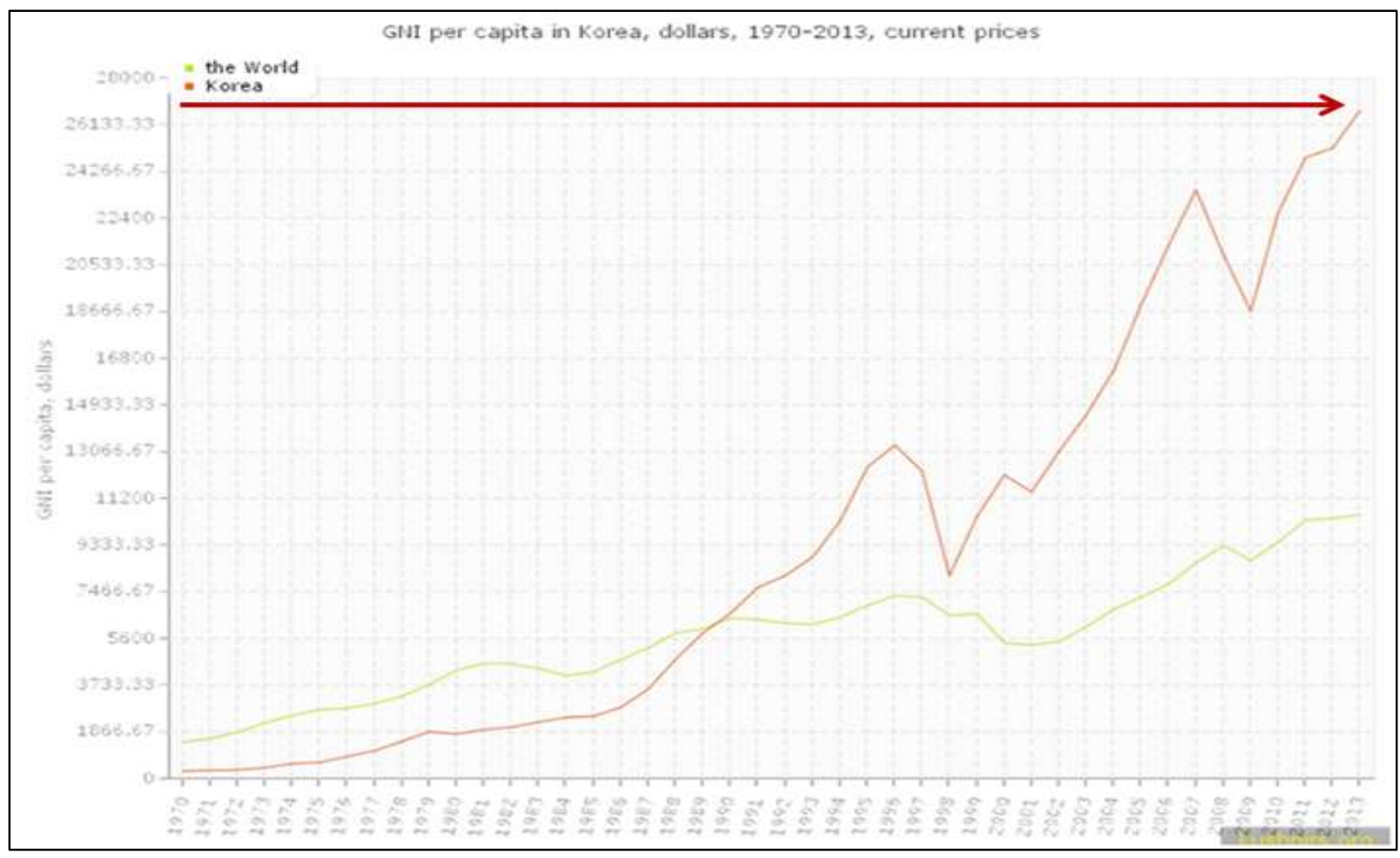

Fig. 4: Gross National Income per capita in Korea (http://kushnirs.org/macroeconomics/gni/gni_korea.html)

Until the present time, Korean higher education has dramatically increased in terms of manpower requirement and social demand due to the diversity of industrial and social structure, thus contributed to the development of the national economy.

\section{Application to Vietnam}

\section{Research Intensity in Vietnam}

Figure 5 shows that the research intensity of each country is growing at a roughly constant rate. Vietnam, Thailand and Malaysia have been growing rather rapidly, at about 15$16 \%$ annually. However, the research intensity of Vietnam remains 6.5 and 9.5 times lower than Thailand and Malaysia, respectively. In the meantime, it is still three times as high as Indonesia's research intensity and since 2004 has exceeded the Philippines, which maintains an annual growth rate of only $5.7 \%$. China has developed at the fastest rate: about $20 \%$ per year; it has surpassed Thailand and is about to catch up with Malaysia. In contrast, the most advanced economies in the region with high PRIP output have maintained lower annual growth rates, i.e. South Korea, Taiwan, and Singapore: 9-11\% per year, Hong Kong: 5\% per year, and Japan: 1\% per year (Pham, 2010). 


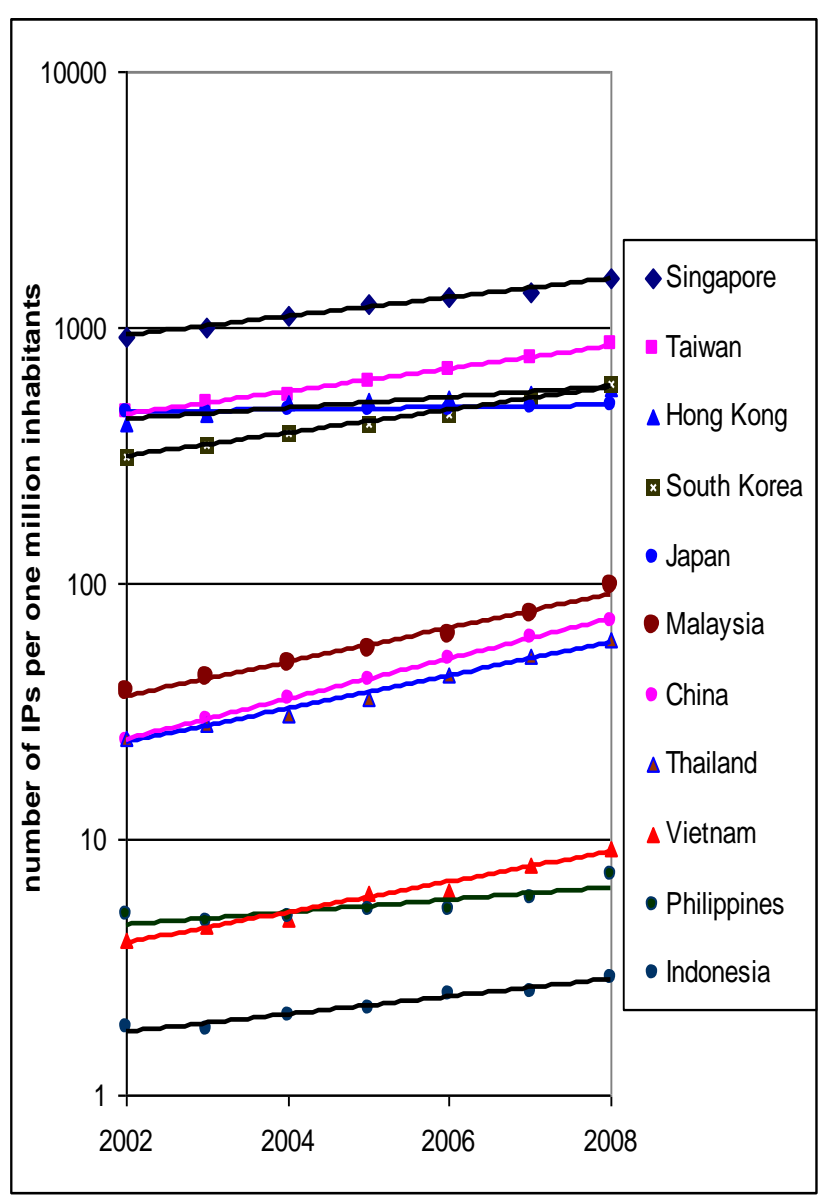

Fig. 5: Number of international publication per one million inhabitants (Source: Pham, 2010)

To a great extent, the gaps in research intensity reflect the different levels of socioeconomic development in the region. Within this group of countries, research intensity correlates strongly with per capita GDP, and reflecting the mutual impact of socio-economic development and scientific research. Economic growth gives rise to increased investment in higher education and high quality scientific research, which in turn enhances the country's capability in technology adaptation and innovation through knowledge creation, dissemination, transfer and utilization (United Nations, 2005; Bernardes and Albuquerque, 2003; Pham, 2010). So Vietnam's higher education, human resource systems should be reformed for the development of science, technology and national economy.

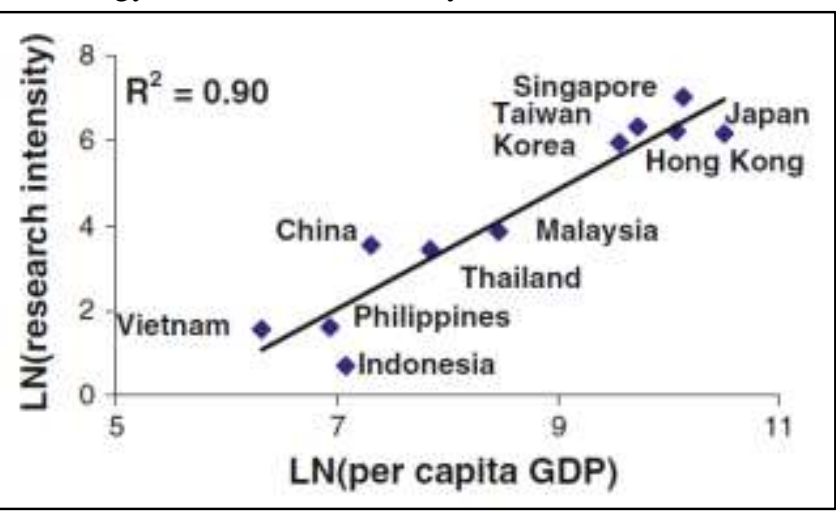

Fig. 6: High correlation of research intensity with per capita GDP (Data for 2004, source: Pham, 2010)

\section{Autonomy in University Education}

Generally, Vietnamese students graduate from high school is at good quality compared to those in other countries. However, a contradiction is seen towards graduate students, especially in laboratory practice, soft skills and working style. In fact, there are a large number of graduate students not working in or related to their major. It proves that Vietnamese university education needs to change. I mean that a road for Vietnam's university education reaching advancement is self-control. Universities needs to have selfcontrol right in recruiting number of lecturers in both teaching and research, in finance and training programs for students, etc.

It is necessary to define who the boss is? It can be regarded as the rector who is the head and has highest responsibility of a university. In Korean universities, a rector is strictly selected and the selection is based on a number of criteria. A rector plays an important role in a university's development.

Teachers' low pay is a great injustice to university lecturers and researchers than sectors in other fields. Income of professors and doctors at universities with long experience may even lower than it is of new bachelors, masters, or engineers working for corporations and foreign companies. This creates a huge waste of labor power universities due to lack of good working conditions, and concerns about their financial matter. And only when they have enough salary, standards for working conditions are provided, together with appropriate policies for the development, it will be able to train highly qualified human resources, develop science and technology development, linking to develop industry, and create a leverage for the development of national economy.

Some universities in Vietnam has been piloted financial autonomy, they give higher salaries for faculty and staff members than other universities. Accordingly, the results of research, teach and output of students had changed in a good way. In the current situation of Vietnam, the autonomy for universities can be considered as one of the effective measures for the development of higher education. Public schools cannot afford to meet the needs of society will gradually be changed or eliminated themselves (Tran, 2015).

\section{Construction for Personnel Resources in Higher Education}

Vietnamese people often say: "Good teacher, good student", so greatly contributed to the development of teaching and research are faculty members and researchers. During research on personnel matters of Vietnamese universities today, we think the way they do as opposed to faculty selection's process of successful universities in the world. The recent way in Vietnam universities for recruitment is to build personnel from their school. Universities often choose their best students to train them become the main human source for their faculty and research members. Most 
universities in the world have policies not to recruit their students as faculty members after graduation. Currently, Vietnam government is implementing policies to attract the overseas Vietnamese scientists and intellectuals to contribute their knowledge to their homeland. Under the terms of the policy, it will bring high value to higher education as well as the development of science and technology in Vietnam if it is done with a clear roadmap and have a proper development. We think overseas Vietnamese scientists and intellectuals have very significant potential and they are willing to devote to the country, but there are still subject to restrictions by some reasons. The problems could be lack of information, "bridge", and method for policy implementation (Tran, 2015).

Vietnam and Korea have quite much similar in culture and history (Bach, 2013; Bach, 2014). What made the success of South Korea was the consensus and determination of the Korean people and their government, and a huge contribution of overseas Korean who return to the country participated in the development of the country. With the rise boom in higher education, science and high technology in a short time, along with the special policies from the government, consent of the competent authorities, Republic of Korea has become a developed country. As living, working and studying in Korea for long time, as well as tracking the moves of our homeland, we have a strong belief that Vietnam could have a development process and success like Korea.

Vietnamese overseas compatriots living abroad have nearly 4.5 million people, of which nearly 400,000 people are professionals and intellectuals. Vietnam's education could be successful if we know how to exploit effectively this human source, as well as to find appropriate ways to combine abroad and local human resources. Unity creates strength is the lesson which has been proven in Vietnamese history. If each Vietnamese person has the same effort, solidarity, which gathers foreign and domestic resources into the overall strength, in accordance with suitable policies and support from Vietnam government, we believe that Vietnam will develop more far-reaching than it is at the moment (Tran, 2015).

\section{Outline for Some Proposals to Vietnam}

- First, autonomy for universities can be considered as one of the effective measures for the development of higher education. Schools cannot afford to meet the demands of society will be gradually changed or eliminated themselves.

- Second, the rights for appointing professors for the universities should be follow the same model as the developed countries have been doing. It should be based on their publications on international scientific journals, patents of inventions, or gained other important scientific achievements.

- Third, give the responsibility and confidence to the intelligentsia oversea Vietnamese. Create opportunity to dedicate and prove their ability in the homeland.

- Fourth, recruit and support financially for those have relevant expertise to which the society and country need. Fund for these teams should be enough for their needs, at the focus on research and development of science and technology. Conversely, they must fulfill the requirements with specific tasks and take responsibilities under state commitments.

- Fifth, encourage scientific domestic journals to reach international level. Because nowadays, the number of journals at international level could be counted on the fingers of one hand, and consequently most articles published in the Vietnamese journal are not much recognized in the world, and manuscripts from Vietnam are often encounter difficulties when publishing on international journals.

- Sixth, a dramatic improvement in building, selecting and evaluating programs for scientific and technological subjects is needed.

- Seventh, policies on science, technology and education need to enhance the value of scientific research quality (based on the number of articles that published in the international journal and the citation index). The Vietnamese big companies should be established the research and development centers, and strengthening the cooperation with universities in research, then manufacturing high-quality products, and creates value for the development of the economy.

- Eighth, focus on improving 10 key universities of Vietnam with the 10-years strategy to improve the ranking of universities according to international levels (set targets to World University Top 200). Vietnam should establish strategic programs similar to the Brain Korea 21 program which Korea has been doing orientate and link between higher education and the young researchers, highly qualified human resources for the development of science, technology and national economy.

\section{Conclusions}

As an economy develops toward an advanced level, technological competence becomes a critical factor. To build up the competence, it is required to nurture highcaliber scientists and engineers who are capable of dealing with the developments at scientific and technological frontiers. In other words, advanced education in science and technology should come first in preparing for entrance into a developed world. In the case of Korea, education and industrialization helped each other in sustaining and accelerating mutual development. Education made technological learning and therefore industrialization 
possible, while industrialization enhanced the rate of return on investment in education, further promoting demand for education. Two major lessons from the Korean experiences are: First, human resource is the key to science and technology development and thus to economic growth, and second, nothing can better motivate private businesses to invest in technology development than market competition (Chung, 2010). Experiences in higher education reform in Korea are valuable lessons and can be applied in Vietnam. The above review suggests the approaches for reshaping higher education system, human resources, science and technology in Vietnam. The country must focus to the policies and real activities for building internationalrecognized standards in teaching, studying, research and governance. If the suggestions above can be done, it will be create a new face of Vietnam's higher education, science and technology, as well as for national economy.

\section{Acknowledgements}

This work was supported by the Fund for Vietnam's sea, island sovereignty, established by the Association of Vietnamese Communities in Korea, for which the authors are thankful.

\section{References}

Bach TNT (2014) Similarities of Vietnam and South Korea Linking to the Strategy Cooperation Partnership and Its Future Direction. Int. J. Soc. Sci. Manage. 1: 88-92.

Bach TNT and Kim YS (2015) Reservation and development for Vietnamese Dong Ho Folk Paiting. Int. J. Soc. Sci. Manage. 2(2): 157-164.

Baek SG (2013) Education and Economic Growth - Korean Exrerience. Korean Educational Development Institute.

Bernardes A and Albuquerque E (2003) Cross-over thresholds, and interactions between science and technology: Lessons for less developed countries. Research Policy 32: 865885 .

Chung SC (2010) Innovation, Competitiveness, and Growth: Korean Experiences. Annual World Bank Conference on Development Economics, Global.

Kim LS (1997) Imitation to Innovation, The Dynamics of Korea's Technological Learning, Cambbridge: Harvard Business School Press

Lee CJ, Kim Y and Byun SY (2012) The rise of Korean education from the ashes of the Korean War. Prospects 42: 303-318.
Lee HJ (2009) Higher Education in Korea. Seoul National University, Korea.

Lee JK (2000a) Administrative Structure and Systems in Korean Higher Education, Higher Education Management, 12 (2), 43-51.

Lee JK (2000b) Main Reform on Higher Education Systems in Korea, Revista Electronica de Investigacion Educativa, 2(2), http ://redie.ens.uabc.mx/.

Lee JK (2001) Korean Experience and Achievement in Higher Education. Korean Educational Development Institute and Hongik University. http://sspace.snu.ac.kr/bitstream/10371/70596/1/vol11_1.pdf.

Ministry of Education (1976) Education in Korea. Seoul, Korea.

Ministry of Education (1998a) Education in Korea. Seoul, Korea.

Ministry of Education (1998b) Educational Reform toward the 21 st Century in Korea. Seoul, Korea.

Ministry of Education (1999) A Five Year Plan for Educational Development. Seoul, Korea.

Ministry of Education (2000) Education in Korea. Seoul, Korea.

Organization for Economic Cooperation and Development (OECD) (2000). Education at Glance: OECD Indicators. Paris: OECD.

Pham DH (2010) A Comparative Study of Research Capacities of East Asian Countries and Implication for Vietnam. Higher Education, (60): 615-625.

Sam Ro (2014) I Just Learned South Korea's Secret to Competing in Global Trade. http://www.businessinsider.com/southkoreas-rd-spending-2014-6.

Seong S, Popper SW, Goldman CA and Evans DK (2008) Brain Korea 21 phase II: A new evaluation model. Rand Corporation..

Soh HS (2013) Higher Education Innovacy in Korea. Korea International Cooperation Agency.

Tran HL (2015) Higher education reform for science, technology and economy development in Korea and applications in Vietnam. Presentation in National Conference for Vietnamese experts in overseas, Hanoi, Vietnam.

United Nations (2005) World investment report-transnational corporations and the internationalization of $\mathrm{R} \& \mathrm{D}$, New York and Geneva. 